\title{
USULAN PEMANFAATAN TEKNOLOGI MODIFIKASI CUACA DENGAN GROUND-BASED GENERATOR UNTUK MENAMBAH DEBIT ALIRAN SUNGAI MAMASA, SULAWESI
}

\author{
Tri Handoko Seto dan Erwin Mulyana \\ UPT Hujan Buatan BPPT
}

\begin{abstract}
Intisari
Telah didesain sebuah usulan pemanfaatan teknologi modifikasi cuaca (TMC) dengan ground-based generator (GBG) untuk menambah debit aliran sungai Mamasa di Sulawesi guna meningkatkan produksi listrik dari Pembangkit Listrik Tenaga Air (PLTA) Bakaru. GBG adalah metode alternatif operasi penyemaian awan dari darat menggunakan menara. Penelitian tentang GBG telah selesai dilakukan di kawasan Puncak Bogor yang merupakan bagian dari sistem orografik Gunung Gede-Pangrango. Daerah Aliran Sungai (DAS) Mamasa memiliki kemiringan lereng antara $25 \%-40 \%$. Topografi dengan kelerengan curam berada di bagian tengah, sebagian kecil di bagian hulu serta di bagian hilir DAS. Faktor orografi sangat dominan dalam pembentukan awan di DAS Mamasa. Uap air yang masuk ke DAS dipaksa naik oleh pebukitan di batas DAS sehingga terjadi pembentukan awan. Bagian tengah DAS sisi sebelah barat (Sikuku dan Sumarorong) memiliki curah hujan paling banyak sedangkan bagian tengah sisi sebelah timur (Rippung, Tabone, Tatoa dan Salembongan) memiliki curah hujan paling rendah. Hasil kajian topografi merekomendasikan wilayah Sikuku, Makuang dan Sumarorong sebagai lokasi menara GBG. Sementara itu, Polewali direkomendasikan untuk lokasi radar. Karena DAS Mamasa adalah daerah yang rawan longsor maka pembangunan menara GBG disarankan dilakukan pada bulan bulan tidak banyak hujan yaitu pada bulan Juni sampai dengan Agustus.
\end{abstract}

Kata kunci: teknologi modifikasi cuaca (TMC), ground-based generator (GBG), DAS Mamasa.

\begin{abstract}
A proposed use of weather modification technology (TMC) with ground-based generator (GBG) to increase Mamasa river flow in Sulawesi to increase electricity production from Bakaru hydropower was designed. GBG is an alternative method of cloud seeding operations from the ground using towers. Research on GBG has been completed in the area of Puncak, Bogor, which is part of the orographic system Gunung Gede-Pangrango. Mamasa Watershed has a slope of between 25\% -40\%. Topography with steep slopes are in the middle, a small portion in the upstream and in the downstream of watershed. Orography is very dominant factor in the formation of clouds in the Mamasa watershed. Water vapor that enters the watershed is forced up by the hills in the watershed resulting in the formation of clouds. The middle part of west side (Sikuku and Sumarorong) have the most rainfall, while the central part of the eastern side (Rippung, Tabone, Tatoa and Salembongan) has the lowest rainfall. Results of the assessment of topography recommend the area of Sikuku, Makuang and Sumarorong as GBG tower locations. Meanwhile, Polewali recommended for radar location. Because Mamasa watershed is an area that is prone to landslides, the construction of the GBG tower suggested carried out during June to August.
\end{abstract}

Key words: weather modification technology (TMC), ground-based generator (GBG), Mamasa watershed.

\section{PENDAHULUAN}

Ground-Based Generator (GBG) adalah sistem penghantar bahan semai ke dalam awan yang bersifat statis yang dilakukan dari permukaan tanah. Teknologi modifikasi cuaca (TMC) dengan GBG dalam penyemaian awan dapat mengurangi ketergantungan pada pemakaian pesawat terbang sehingga relatif lebih murah. Teknologi GBG ditujukan terutama untuk penyemaian awan Cumulus dan Orografik di sekitar puncak gunung 
yang tidak bisa dijangkau pesawat terbang karena alasan keselamatan penerbangan. Selain itu, teknologi ini diperuntukkan bagi wilayah yang menginginkan jasa modifikasi cuaca namun wilayah tersebut tidak memiliki fasilitas pangkalan penerbangan.

Teknologi GBG merupakan pengembangan Teknologi Menara Dispenser yang penelitiannya telah dilakukan oleh BPPT tahun 1983 - 1989 di lereng Gunung Tangkuban Perahu Jawa Barat. Menara Dispenser pada waktu itu menggunakan alat peluncuran bahan dengan sistem micronair, dan bahan semai berbentuk liquid (larutan).

Unit Pelaksana Teknis Hujan Buatan BPPT telah menyelesaikan penelitian lanjutan tentang metode alternatif operasi penyemaian awan menggunakan menara GBG. Penelitian ini dilakukan di kawasan Puncak Bogor yang merupakan bagian dari sistem orografik Gunung Gede-Pangrango.

Hasil penelitian ini telah menunjukkan bahwa TMC dengan GBG cukup efektif untuk dijadikan alternatif bagi TMC yang biasanya menggunakan pesawat terbang sebagai sarana penghantar bahan semai, sepanjang memenuhi beberapa persyaratan geografi dan sistem pertumbuhan awan. Teknologi alternatif ini mempunyai kelebihan yaitu jauh lebih murah dibandingkan dengan menggunakan pesawat terbang. Bahan semai yang digunakan dalam teknologi GBG adalah flare higroskopis yang dibakar di puncak menara. Partikel hasil pembakaran flare yang bersifat higroskopis ini akan masuk ke dalam awan terbawa angin lembah di sekitar lokasi menara.

Pada tahun 2011 telah dilakukan penelitian pendahuluan tentang kelayakan teknis penerapan TMC dengan GBG untuk meningkatkan aliran air sungai Mamasa bagi PLTA Bakaru. Hasil kajian aspek topografi, meteorologi dan klimatologi serta sistem pembentukan awan di daerah aliran sungai Mamasa merekomendasikan teknologi GBG dapat diaplikasikan untuk meningkatkan aliran air bagi PLTA Bakaru.

Tujuan pemanfaatan TMC dengan GBG adalah untuk menambah debit aliran Sungai Mamasa terutama pada saat musim transisi untuk menjaga ketersedian air bagi pembangkit PLTA Bakaru.

\section{KAJIAN TMC DENGAN GBG}

\subsection{Proses Hujan Alam}

Ketika uap air terangkat naik ke atas oleh aktivitas konveksi ataupun oleh adanya bukit atau gunung, uap air tersebut akan mengembun pada level tertentu. Karena bersifat higroskopik maka sejak berlangsungnya kondensasi, partikel berubah menjadi tetes cair (droplets) dan kumpulan dari banyak droplets membentuk awan. Jika kelembaban masih mendukung terutama pada lapisan di bawah dasar awan kondensasi terus berlangsung hingga droplets mencapai ukuran sekitar 30 mikron dan secara fisik terlihat dengan makin besarnya awan. Jika di antara partikel terdapat partikel besar dengan ukuran sekitar 4050 mikron. Maka partikel yg lebih besar tersebut dalam gerak turun ia akan lebih cepat dari yang lainnya sehingga bertindak sebagai "pengumpul" karena sepanjang lintasannya ke bawah ia menumbuk tetes lain yang lebih kecil, bergabung dan menjadi jauh lebih besar lagi (proses tumbukan-penggabungan). Proses ini berlangsung ber-ulang ulang dan merambat ke seluruh bagian awan hingga jatuh sebagai hujan dengan ukuran sekitar 1000 mikron atau lebih besar.

\subsection{Teknologi Modifikasi Cuaca}

$\begin{array}{cccc}\text { Teknologi Modifikasi } & \text { Cuaca } & \text { (TMC) } \\ \text { merupakan suatu upaya manusia dalam }\end{array}$
memanfaatkan kondisi cuaca dan iklim di suatu wilayah untuk tujuan tertentu yang bermanfaat. Kegiatan TMC pada umumnya digunakan untuk mengatasi bencana iklim dan cuaca seperti kekeringan, kebakaran hutan dan banjir. Metode yang digunakan dalam TMC adalah dengan menyemai awan menggunakan pesawat terbang, roket, artileri dan GBG seperti ditunjukkan pada Gambar 1 pada halaman berikut. Kegiatan TMC di Indonesia selama ini dilakukan dengan pesawat terbang dan GBG.

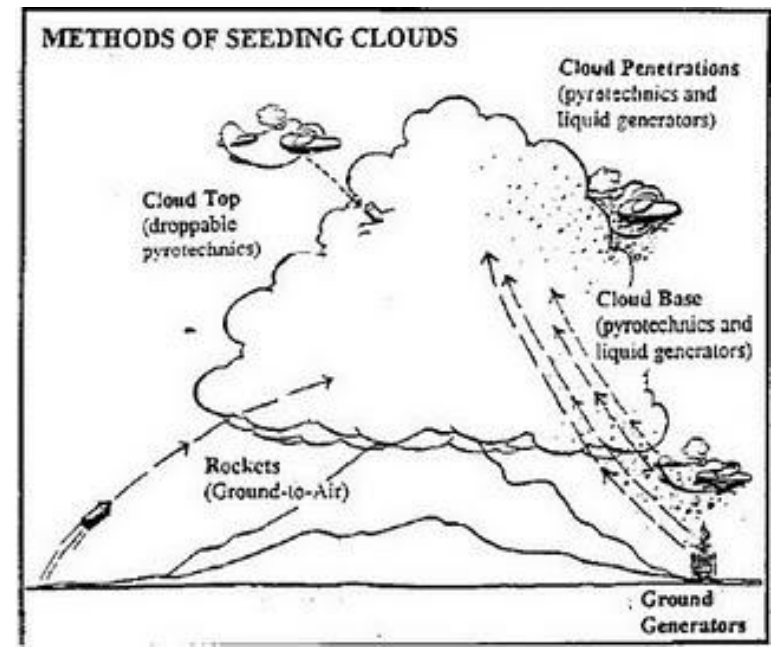


Gambar 1. Metode penyemaian awan yang digunakan dalam kegiatan TMC di dunia. Cara dinamis dengan pesawat terbang dan cara statis dari darat dengan menggunakan roket dan ground-based generator.

\subsection{Penyemaian Awan dari Darat dengan GBG}

Unit Pelaksana Teknis Hujan Buatan BPPT telah mencoba berbagai upaya penyemaian awan dari darat yang diawali dengan didirikannya menara GBG sebagai wahana penyampaian bahan semai ke dalam awan. Penyemaian awan dengan sistem GBG ini terutama untuk melakukan penyemaian awan yang berpotensi hujan yang ada di sekitar puncak dan lereng lereng gunung.

UPT Hujan Buatan BPPT telah menyelesaikan penelitian tentang metode alternatif operasi penyemaian awan dari yang biasanya menggunakan pesawat terbang dengan menggunakan menara GBG. Penelitian ini dilakukan di kawasan Puncak Bogor yang merupakan bagian dari sistem orografik Gunung Gede-Pangrango.

Hasil penelitian menunjukkan bahwa TMC dengan GBG cukup efektif untuk dijadikan alternatif bagi TMC menggunakan pesawat terbang sebagai sarana penghantar bahan semai, sepanjang memenuhi beberapa persyaratan geografi dan sistem pertumbuhan awan.

\subsection{Kondisi Geografis}

Daerah Aliran Sungai (DAS) Mamasa berada di dua propinsi, yaitu Provinsi Sulawesi Barat yang merupakan bagian hulu DAS Mamasa dan Provinsi Sulawesi Selatan yang merupakan bagian hilir DAS Mamasa. Ada lima kabupaten yang berada di DAS Mamasa, Kabupaten Mamasa dan Kabupaten Polewali Mandar di Sulawesi Barat serta Kabupaten Pinrang, Kabupaten Enrekang, dan Kabupaten Tana Toraja di Sulawesi Selatan. Luas DAS Mamasa kurang lebih 118.500 hektar dengan bentuk memanjang dari utara ke selatan seperti diperlihatkan pada Gambar 2.

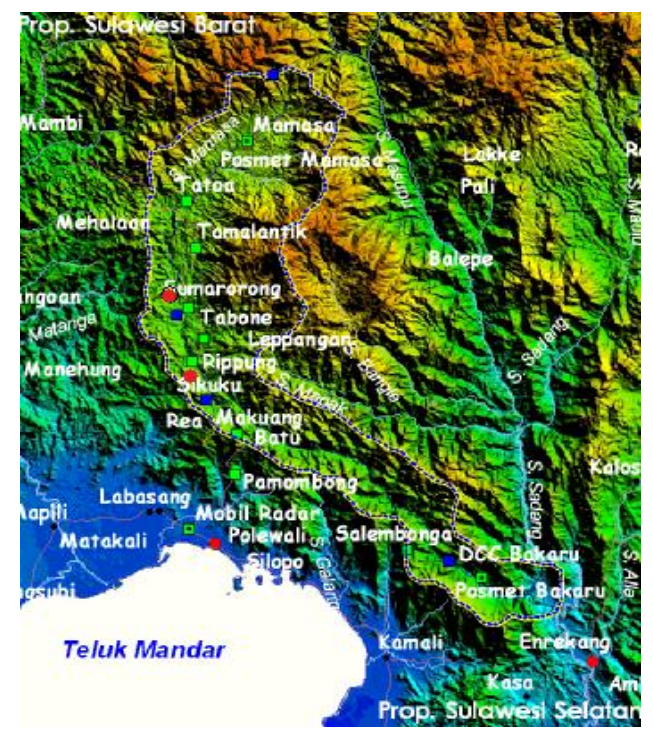

\begin{tabular}{|l|l|}
\hline Gambar 2. & $\begin{array}{l}\text { Daerah Aliran Sungai Mamasa yang } \\
\text { merupakan sumber air untuk PLTA } \\
\text { Bakaru. }\end{array}$ \\
\hline
\end{tabular}

Daerah Aliran Sungai Mamasa umumnya bertopografi sedang hingga curam yaitu rata-rata kemiringan lereng antara $25 \%-40 \%$. Topografi curam tersebar pada daerah hulu, daerah tengah, dan daerah hilir yang umumnya bergunung dengan ketinggian berkisar antara $500 \mathrm{~m}$ hingga 2500 meter. Sebagian besar topografi dengan kelerengan curam berada pada bagian tengah, sebagian kecil pada daerah hulu DAS, serta sebagian kecil lagi berada pada daerah bagian hilir. Total luas topografi dengan kelerengan curam seluas 39,654 ha atau $33,47 \%$ dari total luas DAS Mamasa. Dan topografi dengan kelerengan landai yaitu $8 \%-15 \%$ hanya berada pada bagian hulu DAS yaitu pada daerah Kecamatan Mamasa seluas 6.343 $\mathrm{Ha}$ atau $5,35 \%$ dari luas DAS Mamasa.

\section{PELAKSANAAN}

\subsection{Pembangunan Infrastruktur}

Pembangunan infrastruktur yang diperlukan untuk menunjang kegiatan pelaksanaan TMC dengan GBG adalah meliputi: pembangunan menara GBG, pembuatan remote burning system dan instalasi radar cuaca.

\subsubsection{Menara GBG}

Menara GBG berfungsi untuk menempatkan sejumlah bahan semai flare. Bahan semai flare ini ditempatkan di bagian ujung dari menara GBG. 
Proses penempatan flare di ujung menara dilakukan dengan cara system katrol (kerekan). Susunan flare yang ditempatkan dalam wadah khusus (flare tree) kemudian di tarik dengan sistem katrol. Sistem katrol ini bisa manual maupun dengan penggerak motor listrik tergantung dengan ketersediaan sumber listrik di lapangan.

Menara GBG yang dimaksudkan dalam kegiatan ini adalah menara yang terbuat dari besi dengan ukuran diameter tertentu dan dalam bentuk segitiga sama sisi (triangles tower). Tinggi menara GBG yang diperlukan setinggi $50 \mathrm{~m}$. Untuk mendapatkan ketinggian menara setinggi $50 \mathrm{~m}$ tersebut dibuat dengan cara menyusun tiang menara segitiga sebanyak 10 buah, dimana tinggi menara masing-masing stek adalah $5 \mathrm{~m}$. Untuk menjaga dan menopang agar susunan menara segitiga tetap berdiri tegak vertical, maka setiap stek diikat dengan tali baja yang ujungya diikat secara permanen di ground. Untuk menopang beban menara dan agar posisi menara tidak mengalami perubahan, maka sebelum pemasangan menara harus disiapkan dahulu pondasi sebagai dudukan menara.

Contoh Menara GBG yang telah terpasang milik BPPT dapat dilihat pada Gambar 3. Terkait dengan rencana kegiatan TMC dengan GBG di DAS Mamasa, lokasi penempatan menara GBG direncanakan di daerah Sumarorong dan Sikuku. Masing-masing daerah akan ditempatkan 2 (dua) buah menara GBG yang sebaran lokasinya akan disesuaikan dengan aksesibilitas menuju lokasi. Pemilihan daerah Somarorong dan Sikuku ini berdasarkan hasil kajian dari berbagai aspek seperti: meteorologi, klimatologi dan topografi. Sebaran rencana lokasi menara GBG dapat di lihat pada Gambar 2.

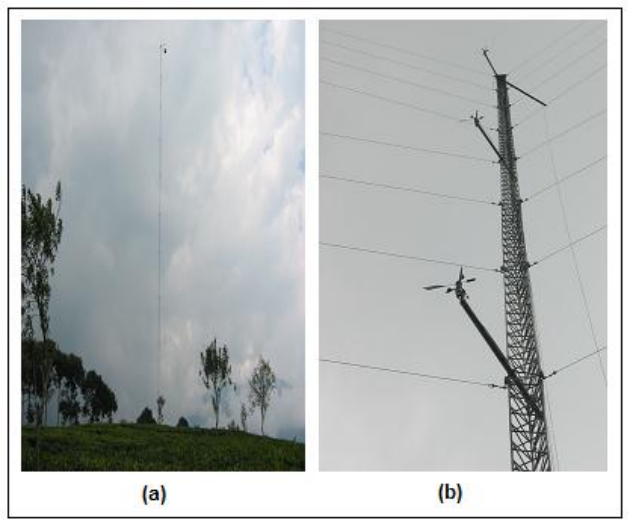

Gambar 3. (a). Contoh menara GBG milik BPPT yang telah terpasang. (b). Contoh menara triangle

\subsubsection{Radar Cuaca}

Radar cuaca dimanfaatkan untuk memonitor pertumbuhan awan yang tumbuh dan atau bergerak melintasi menara GBG. Tingkat keberhasilan penyemaian awan sangat ditentukan oleh adanya awan yang tumbuh dan atau bergerak melintasi menara GBG. Oleh karena itu penempatan lokasi radar harus mampu memantau perkembangan awan di daerah target terutama di lokasi menara GBG. Lokasi radar yang paling optimal untuk memantau kondisi awan untuk mendukung pelaksanaan TMC adalah di Polewali. Pembentukan awan orografik di sisi sebelah barat batas DAS, yaitu di Sumarorong dan Sikuku akan terpantau dengan baik oleh radar yang ditempatkan di Polewali.

Radar yang diperlukan untuk mendukung pelaksanaan TMC di DAS Mamasa adalah radar cuaca dengan spesifikasi dasar sebagai berikut:

Tipe radar: X-band weather radar

Jangkauan: radius minimum $75 \mathrm{~km}$

Dimensi: Memungkinkan di-mounted di mobil

Ada 2 macam radar yang sesuai dengan spesifikasi di atas dan direkomendasikan untuk diinstal di Polewali, yaitu :

1. TWR Weather Radar, dengan spesifikasi :

- Jangkauan pengamatan maksimum $120 \mathrm{~km}$

- Diameter antenna $1 \mathrm{~m}$

- Berat $\leq 70 \mathrm{~kg}$

- Beam width $\leq 3.0^{\circ}$

- Perkiraan harga Rp. $2 \mathrm{M}$

- Diproduksi di China

2. EWR Weather Radar :

- Jangkauan pengamatan maksimum $150 \mathrm{~km}$

- Diameter antenna $70 \mathrm{~cm}$

- Berat $65 \mathrm{~kg}$

- Beam width $3.3^{0}$

- Perkiraan harga Rp. $7 \mathrm{M}$

- Diproduksi di Amerika

\subsection{Pelaksanaan TMC}

Kegiatan TMC dengan GBG akan dilaksanakan setiap hari mulai pagi hari hingga sore hari. Kegiatan operasioanal dipusatkan di Posko yang akan memberikan instruksi ke setiap menara GBG. Di posko setiap hari akan menerima kiriman data baik data cuaca permukaan maupun data 
radar. Data cuaca permukaan akan dikirimkan ke posko dengan interval setiap jam mulai dari jam 08.00 hingga 18.00. Demikian juga data radar akan dikirimkan setiap jam atau dengan interval yang lebih pendek, bila di daerah target telah dijumpai pertumbuhan awan-awan potensial.

Berdasarkan data yang telah dikirim ke Posko, kemudian dilakukan analisis data secara komprehensif, yaitu selain data local juga dilakukan analisis global yang meliputi citra landsat, gradient wind dan data global lainnya. Bila hasil analisis keseluruhan data tersebut mengindikasikan bahwa di daerah target khsusnya di sekitar lokasi menara GBG telah mencapai kondisi cuaca yang mendukung (favourable) untuk penyemaian awan, maka posko akan memberikan instruksi kepada petugas di setiap menara GBG untuk menyalakan flare. Bila sistem teleburning telah berfungsi dengan maksimal, maka proses penyalaan flare dapat dilakukan langsung dari posko. Bila kondisi cuaca dalam hari itu sangat mendukung, maka kegiatan penyalaan flare bisa berlangsung lebih dari satu kali. Wilayah cakupan kerja TMC GBG di DAS Mamasa seperti pada Gambar 4.

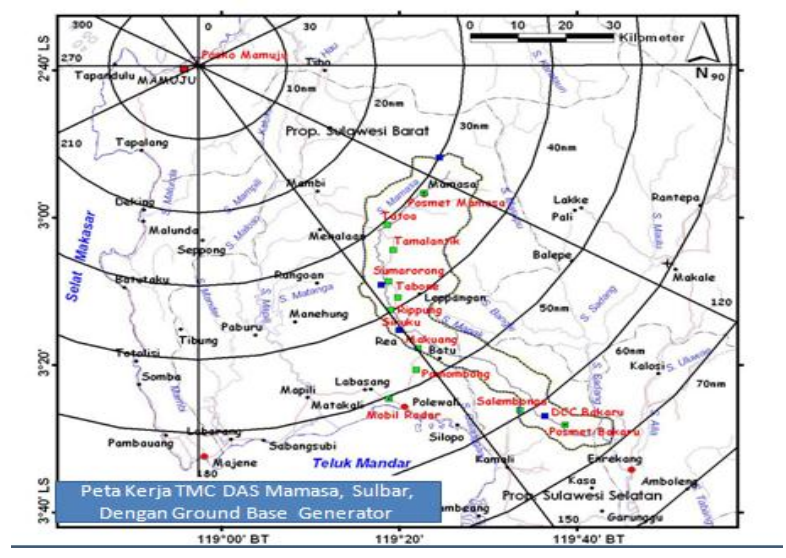

Gambar 4. $\quad$ Peta kerja kegiatan TMC dengan GBG di DAS Mamasa, Sulbar.

\subsubsection{Pekerjaan persiapan}

Pekerjaan yang harus dilakukan dalam tahap persiapan ini meliputi beberpa hal, yaitu pekerjaan persiapan menyangkut kesiapan menara, bahan semai, instalasi radar, instalasi remote burning dan instalasi pusat komando (Posko).

Kesiapan menara difokuskan pada pengecekan kinerja menara. Apakah menara telah siap untuk digunakan dan tidak terjadi hal-hal yang dapat menghambat kelancaran kegiatan, seperti : sistem katrol, tali katrol, tali penguat menara, tempat pemasangan flare (flare tree) dan remote burning system. Bila semua item tersebut sudah dalam kondisi baik dan dapat berfungsi, maka pekerjaan TMC yang menyangkut dengan menara GBG dapat dinyatakan siap.

\subsubsection{Pengukuran dan analisis cuaca}

Untuk mendukung kegiatan operasional GBG, di wilayah target dilengkapi dengan peralatan pengukuran cuaca seperti : Temperatur (T), Kelembaban (Rh), arah dan kecepatan angin. Peralatan cuaca akan ditempatkan di setiap menara GBG dan hasil pengukurannya akan dikirimkan secara otomatis ke Posko. Data cuaca yang masuk ke posko selanjutnya dianalisis untuk mengetahui perkembangan perubahan cuaca di wilayah target.

\subsubsection{Observasi dengan Radar}

Radar yang ditempatkan di Polewali dapat memantau awan yang tumbuh dan atau bergerak melintasi menara GBG yang berada di Sumarororng dan Sikuku. Pengoperasian radar dilakukan setiap hari selama pelaksanaan penyemaian awan dengan TMC GBG. Radar dinyalakan setiap hari dari jam 10.00 s.d 18.00. Hasil monitoring radar serta analisis cuaca lainnya digunakan untuk menentukan waktu penyalaan flare.

\subsubsection{Kegiatan Penyemaian dengan GBG}

Kegiatan penyemaian awan dengan menara GBG dilakukan setiap hari disesuaikan dengan kondisi cuaca dan pertumbuhan awan di daerah target. Tahapan pelaksanaan penyemaian awan dengan GBG secara umum adalah sebagai berikut :

1. Pagi hari dimulai dengan briefing, membahas mengenai kegiatan hari sebelumnya dan prediksi kondisi cuaca hari yang bersangkutan. Kegiatan briefing dipimpin oleh Koordinator Lapangan dan diikuti oleh semua peneliti dan personil yang bertugas di posko

2. Personil yang bertugas terkait dengan tugasnya masing-masing menyampaikan hasil analisisnya. BMKG akan memberikan hasil analisis cuaca dan prediksi cuaca hari itu, Personil Hidrologi dan Lingkungan menyampaikan hasil pengkuran curah hujan di daerah target, Bagian Data menyampaikan hasil pengukuran dan analisis cuaca permukaan, Bagian Perlengkapan menyampaikan stok bahan semai dan kesiapan peralatan di lapangan 
3. Petugas Radar menyampaikan kondisi awan yang telah terpantau dan perkembangan kondisi pertumbuhan awan ke depan

4. Berdasarkan hasil masukan data yang telah diperoleh, maka koordinator memutuskan status kegiatan, apakah penyemaian awan dengan GBG akan dilakukan segera atau masih menunggu perkembangan kondisi cuaca di target.

5. Bila kondisi cuaca telah mencapai kriteria tertentu yang mengindikasikan bahwa kondisi cuaca dan pertumbuhan awan sangat mendukung untuk penyemaian awan, maka koordinator mengintruksikan kepada petugas menara GBG untuk melakukan penyalaan flare. Penyalaan flare bisa dilakukan secara manual ataupun otomatis menggunakan system teleburning.

\section{EVALUASI}

Kegiatan operasional TMC akan di evaluasi secara kuantitatif dan kualitatif. Untuk menunjang evaluasi tersebut akan dipasang sebanyak 12 buah penakar hujan. Selain itu akan dipantau dengan menggunakan radar hujan, untuk mengetahui keberadaan awan dan peluang hujan setiap harinya dan juga akan dipantau dengan menggunakan data satellite TRMM. Untuk evaluasi kondisi lingkungan akan dipantau dampak lingkungan akibat dari operasional TMC dengan memasang 2 peralatan sample kualitas air hujan dan 1 peralatan untuk pengambilan sample air waduk. Untuk keperluan monitoring rona lingkungan akan dilakukan pemotretan tanaman-tanaman komoditi yang dominan di daerah target dan sekitarnya.

\subsection{Monitoring Curah Hujan}

Untuk memonitoring curah hujan akan digunakan penakar hujan, radar dan data satellite TRMM. Penakar hujan akan dipasang di DAS Mamasa sebanyak sekitar 12 buah. Pemasangan penakar ini akan dikombinasikan dengan penakar yang sudah ada di DAS Mamasa, sehingga bisa merepresentasikan kejadian hujan sesungguhnya dalam rangka keperluan evaluasi harian kegiatan TMC.

\subsection{Perhitungan Tambahan Air}

Berdasarkan data inflow yang didapat dari pengelola DAS Mamasa dapat digambarkan bahwa pola inflow DAS Mamasa adalah seperti Gambar 5.

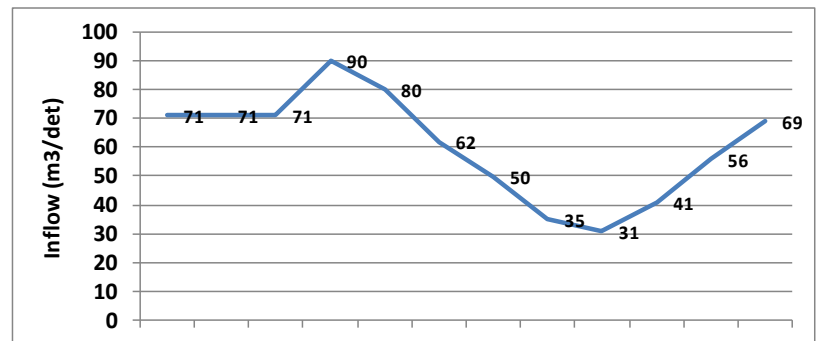

Jan Feb Mar Apr Mei Jun Jul Agt Sep Okt Nov Des Bulan

Gambar 5. $\quad$ Pola inflow (m3/det) DAS Mamasa, Sulbar, dari tahun 1985 - 2006.

Untuk menghitung tingkat tambahan hasil air (\%) akibat penyemaian awan akan digunakan rumus sebagai berikut:

Dimana,

$\mathrm{R}=$ Tingkat penambahan Inflow (\%)

$\mathrm{Qa}=$ Inflow aktual (m3/det), saat ada TMC.

$\mathrm{Qp}=$ Prediksi Inflow (m3/det), seandainya tidak ada TMC.

Untuk memprediksi Inflow seandainya tidak ada operasional TMC, dilakukan dengan menggunakan methode Weibull, lihat Tabel 1.

\begin{tabular}{|l|l|}
\hline Tabel 1. & $\begin{array}{l}\text { Prediksi inflow (m3/det) DAS Mamasa } \\
\text { bulan Januari s/d Desember 2012, } \\
\text { berdasarkan data inflow tahun } 1985 \text { s.d } \\
\\
2006 .\end{array}$ \\
\hline
\end{tabular}

\begin{tabular}{|c|c|c|c|c|c|c|c|c|c|c|c|c|}
\hline PR0B & JAN & PEB & MAR & APR & MEI & JUN & JUL & AGS & SEP & 0KT & NOP & DES \\
\hline \hline $40 \%$ & 80,47 & 75,15 & 71,69 & 89,92 & 90,61 & 68,35 & 52,09 & 34,90 & 31,10 & 44,52 & 65,23 & 72,33 \\
\hline $50 \%$ & 69,17 & 70,26 & 68,48 & 85,25 & 84,59 & 63,76 & 46,66 & 32,31 & 26,92 & 41,84 & 56,25 & 67,81 \\
\hline $60 \%$ & 62,56 & 64,77 & 63,78 & 83,58 & 70,24 & 57,91 & 39,14 & 31,05 & 23,50 & 36,53 & 45,03 & 57,56 \\
\hline $70 \%$ & 59,13 & 61,87 & 58,81 & 77,57 & 69,31 & 50,36 & 36,25 & 27,42 & 20,53 & 23,15 & 31,99 & 53,11 \\
\hline $80 \%$ & 56,94 & 54,18 & 51,78 & 71,07 & 54,51 & 44,97 & 30,45 & 21,16 & 19,23 & 14,45 & 25,27 & 46,61 \\
\hline $90 \%$ & 36,01 & 40,25 & 46,19 & 63,91 & 48,02 & 32,37 & 26,80 & 19,81 & 16,53 & 13,64 & 19,57 & 40,31 \\
\hline
\end{tabular}

Alasan dilaksanakannya kegiatan TMC, biasanya disebabkan karena adanya prediksi curah hujan yang terjadi akan dibawah normal untuk beberapa bulan kedepan, yang akan mengakibatkan jumlah inflow waduk juga akan berada dibawah normal.

Berdasarkan hal tersebut diatas, maka saat ada kegiatan TMC, prediksi inflow yang dipakai adalah prediksi inflow dengan weibull dengan probabilitas antara $70 \%$ dan $80 \%$ ( dibawah normal).

Secara teori, penyemaian awan dengan GBG ini, tingkat penambahan curah hujannya sekitar 10 sampai $15 \%$ dari curah hujan alamnya, hal ini 
akan identik dengan penambahan inflow sebesar 10 sampai $15 \%$ dari inflow alamnya ( inflow yang diprediksi). Untuk itu besarnya tambahan air akibat pelaksanaan TMC dengan GBG, untuk tingkat probabilitas $80 \%$ dan tingkat penambahan air 15 $\%$, untuk bulan Januari s.d Desember 2012 akan di hitung seperti Table 2 berikut:

\begin{tabular}{|l|l|}
\hline Tabel 2. & $\begin{array}{l}\text { Daftar prediksi inflow (m3/det), } \\
\text { tambahan inflow (m3/det) dan } \\
\text { tambahan volume inflow (jt m3), dengan } \\
\text { asumsi prediksi weibull } 80 \% \text { dan tingkat } \\
\text { penambahan inflow } 15 \% .\end{array}$ \\
\hline
\end{tabular}

\begin{tabular}{|c|c|c|c|c|c|c|c|c|c|c|c|c|}
\hline Uraian & JAN & PEB & MAR & APR & MEI & JUN & JUL & AGS & SEP & OKT & NOP & DES \\
\hline $\begin{array}{c}\text { Prediksi inflitow } \\
\text { (m3/det) }\end{array}$ & 56.94 & 54.18 & 51.78 & 71.07 & 54.51 & 44.97 & 30.45 & 21.16 & 19.23 & 14.45 & 25.27 & 46.61 \\
\hline $\begin{array}{c}\text { Tambahan infllow } \\
\text { (m3/det) }\end{array}$ & 8.54 & 8.13 & 7.77 & 10.66 & 8.18 & 6.75 & 4.57 & 3.17 & 2.88 & 2.17 & 3.79 & 6.99 \\
\hline $\begin{array}{c}\text { Tambahan volume } \\
\text { inflow (Juta m3) }\end{array}$ & 22.88 & 19.66 & 20.80 & 27.63 & 21.90 & 17.48 & 12.23 & 8.50 & 7.48 & 5.81 & 9.82 & 18.73 \\
\hline
\end{tabular}

\subsection{Monitoring Lingkungan}

Tujuan kegiatan monitoring lingkungan adalah sesuai dengan program yang dicanangkan oleh Menteri Negara Kependudukan dan Lingkungan Hidup " membangun tanpa merusak atau pembangunan berwawasan lingkungan" yaitu dengan mengamati dampak operasional TMC terhadap linkungannya.

$$
R=\frac{Q_{a}-Q_{p}}{Q_{a}} \times 100 \%
$$

Kegiatan ini meliputi :

a. Pengukuran kualitas air yang mencakup aspek fisik dan kimia

b. Kondisi tanaman, melalui pemotretan tanaman komoditi di daerah target dan sekitarnya.

Kegiatan pengamatan lingkungan dibagi atas 3 (tiga) tahap, yaitu:

a. Tahap I ( sebelum dilaksanakan kegiatan) tahap ini dilakukan untuk memdapat gambaran keadaan lingkungan baik secara kuantitatif dengan analisa air secara kualitatif dan dengan pengamatan secara visual (diskripsi dilapangan) terhadap tanaman yang ada.

b. Tahap II (selama periode kegiatan) tahap ini dilakukan untuk mendapatkan gambaran keadaan kondisi lingkungan karena adanya operasional TMC, sehingga dapat diketahui perubahan-perubahan yang mungkin terjadi akibat adanya operasional TMC. Tahap ini dilakukan pada pertengahan periode operasional TMC.

c. Tahap III (setalah kegiatan), tahap ini dilakukan untuk mendapatkan gambaran daya dukung/kemampuan lingkungan untuk memperbaiki atau memulihkan kambali bila terjadi perubahan akibat adanya operasional TMC.

\subsection{Pelaporan}

Laporan kegiatan TMC berisi tentang semua aktivitas kegiatan dan hasil evaluasi tambahan air dan kualitas air. Laporan kegiatan TMC ini akan diserahkan ke PLN Bakaru dalam waktu 1 bulan setelah kegiatan TMC selesai..

\section{PENUTUP}

- Daerah Aliran Sungai Mamasa memiliki kemiringan lereng antara $25 \%-40 \%$. Topografi dengan kelerengan curam berada di bagian tengah, sebagian kecil di bagian hulu serta di bagian hilir DAS.

- Puncak musim hujan di DAS Mamasa terjadi pada bulan April dan Januari sedangkan hujan terendah terjadi pada bulan Agustus.

- Bagian tengah DAS sisi sebelah barat (Sikuku dan Sumarorong) memiliki curah hujan paling banyak sedangkan bagian tengah sisi sebelah timur (Rippung, Tabone, Tatoa dan Salembongan) memiliki curah hujan paling rendah.

- Faktor orografi sangat dominan dalam pembentukan awan di DAS Mamasa. Uap air yang masuk ke DAS dipaksa naik oleh pebukitan di batas DAS sehingga terjadi pembentukan awan.

- Daerah Sikuku, Makuang dan Sumarorong direkomendasikan untuk lokasi menara GBG.

- Daerah Polewali direkomendasikan untuk lokasi radar PLN-Bakaru.

- Kawasan DAS Mamasa termasuk daerah yang rawan longsor ketika terjadi hujan. Mengingat kondisi tersebut, pembangunan menara GBG disarankan dilakukan pada bulan bulan tidak banyak hujan yaitu pada bulan Juni sampai dengan Agustus.

\section{DAFTAR PUSTAKA}

1. Ahrens, C.D., 1985. Meteorology today. West Publishing Company. 
2. Hadi. Tri W., T. Horinouchi, T.Tsuda, H.Hashiguchi and S.Fukao, 2002 : Sea-Breeze Circulation over Jakarta, Indonesia : A Climatology Based on Boundary Layer Radar Observation. Mon.Wea.Rev., 130 (9), 21532166.

3. Miao J., J.M Kroon, J.Vila, and A.Holtslag, 2003 : Impact of Topography and Land Degradation on the Sea Breeze over Spain. Met.Atm.Phy., 84, 157-170.

4. Mulyana. E., dan Findy. R., 2011 : Analisis Spasiotemporal di DAS Mamasa Sulawesi Barat Berdasarkan Hasil Observasi Radar Cuaca. Jurnal Teknologi Lingkungan, submitted.

5. Mulyana E., dan S. Tikno, 2006. Kajian Angin Permukaan di Lokasi Menara GBG Citeko Cisarua. Jurnal Sains dan Teknologi Modifikasi Cuaca, Vol.7 No.1. Juni 2006.

6. Mulyana E, dan F. Renggono, 2009, Observasi Awan dengan Radar Mobil di Lokasi Ground Based Generator Gunung Gede Pangrango, Jurnal Teknologi Lingkungan.

7. Lee, DS., RD. Kingdon, J.A. Garland, BMR; Jones. 2000. Parametrization of Orographic Enhancement of Precipitation and Deposition in long-term, long range transport model. Ann. Geophyciae 18.1447 - 1466. 